\title{
In Vitro Screening and Selection of Probiotic Lactic Acid Bacteria Isolated from Spontaneously Fermenting Kunu-Zaki
}

\author{
Solakunmi Omotunde Oluwajoba*, Felix Akinsola Akinyosoye, Victor Olusegun Oyetayo \\ Department of Microbiology, School of Science, Federal University of Technology, Akure, Nigeria \\ Email: ${ }^{*}$ solakunmi@yahoo.com
}

Received April 8, 2013; revised May 8, 2013; accepted June 8, 2013

Copyright (C) 2013 Solakunmi Omotunde Oluwajoba et al. This is an open access article distributed under the Creative Commons Attribution License, which permits unrestricted use, distribution, and reproduction in any medium, provided the original work is properly cited.

\begin{abstract}
The present study was conducted to determine the pro-biotic properties in vitro of the lactic acid bacteria isolated from spontaneously fermenting kunu-zaki. Kunu-zaki was processed using composite, non composite, germinated and ungerminated Digitaria exilis (Fonio), Sorghum bicolor (Sorghum) and Pennisetum americanum (Millet) cereals. A total of $150 \mathrm{LAB}$ isolates were obtained from all the fermenting slurries. These $150 \mathrm{LAB}$ isolates were screened for their ability to grow at $\mathrm{pH} 3.0$, resistance against bile salt and ability to inhibit reference test pathogens. Out of these 150 LAB isolates; 21 exhibited good probiotic properties. All the 21 isolates were further identified to specie and subspecies level using standard API50CHL system with all 21 showing good survival $(\mathrm{P}<0.05)$ in a pH 3.0 buffered medium and subsequent resistance to $0.3 \%$ bile. The LAB isolates which survived these conditions consisted of 18 Lactobacillus species, 2 Pediococcus species and 1 Lactococcus specie. These LAB species were further examined for antimicrobial activity against the growth of reference pathogens Staphylococcus aureus 25923, Escherichia coli 25922, Pseudomonas aeruginosa 27853 and Enterococcus faecalis 29212. All 21 LAB species exhibited good inhibition of all test reference pathogens except Lactobacillus fructivorans, Lactococcus lactis sp lactis and L. fermentum which however, showed no zone of inhibition against the growth of E. faecalis. Kunu-zaki made from composite un-germinated Sorghum bicolor (Sorghum) and Pennisetum americanum (Millet) cereal grains contained the highest percentage (52\%) of LAB species which showed good probiotic criteria in vitro. Non composite ungerminated cereals accounted for $33 \%$ of the total probiotic LAB isolates whilst the germinated non composite and composite cereals recorded the lowest percentage $(10 \%)$ and $(5 \%)$ of probiotic LAB respectively. The results of this research study showed that the LAB species isolated from wild fermentation of kunu-zaki beverage fulfilled the criteria for in vitro screening of probiotic characteristics. These LAB species possed potential for further use as probiotic in human preparations and suggested the use of kunu-zaki made from ungerminated composite sorghum and millet grains as a natural probiotic drink.
\end{abstract}

Keywords: Probiotic; Spontaneously Fermenting; Germination; Composite; Non Composite

\section{Introduction}

Lactic acid bacteria are integral to many African fermented foods and a vast amount of literature is available on them. However, only little is documented about the pro biotic properties of these strains. Whether or not a specific probiotic bacterium will have a beneficial effect on health cannot be presumed only through determination of its genus or species [1]. Furthermore, that a particular genus or specie of bacterium mediating probiotic properties in one substrate will continue to mediate such

${ }^{*}$ Corresponding author. effects in another substrate is only a speculation. Such a speculation must be substantiated by research [1]. Kunuzaki is made from fermented cereals and taken as a refreshing drink in many parts of Nigeria today [2]. The drink particularly presents an attractive research interest for identifying organisms with probiotic potentials. This is because the traditional production process of kunu-zaki allows fermenting organisms to still remain viable inside the drink even at the time of consumption. Those who regularly take kunu-zaki have alluded to its seeming health benefit effects. In Nigeria, the drink enjoys large patronage especially amongst low income earners who classify 
the drink as "filling" and a meal in itself. Particularly, regular consumers in Nigeria describe an overall feeling of wellbeing attributed to long term consumption of kunu-zaki. Scientific human studies are however yet to confirm these claims as there is little research detailing confirmation of the probiotic properties of the fermenting organisms in kunu-zaki. "Acha" (Digitaria exilis) commonly referred to as Fonio, Finni,or Hungry rice [3], is probably one of the oldest Africa cereals and classified as one of the lost/forgotten crops of Africa. "Acha" crops are exceptionally tolerant to a wide variety of conditions, particularly drought and poor soil. The grains are widely produced in the area of growth (Bauchi, Plateau, Kaduna States of Nigeria), are uniquely rich in methionine and cystine, and evoke low sugar on consumption, an advantage for diabetics [4]. The use of Acha grains in the making of kunu-zaki has not yet been satisfactorily explored, and literature is a little scanty on the subject. Acha cereal grains offer an attractive interest not only because of the nutritional attributes but also because it may serve as a cheaper option to either the use of sorghum or millet cereal grains in kunu-zaki. This research work therefore sets out to isolate and identify the fermenting lactic acid bacteria, screen the probiotic characteristics in vitro using sorghum and millet as conventional grains and acha grains as a composite mix to both sorghum and millet.

\section{Materials and Methods}

\subsection{Laboratory Production of Kunu-Zaki}

Sorghum; Sorghum bicolor, Millet, Pennisetum americanum and Hungry rice (locally known as Fonio or Acha) Digitaria exilis grains were obtained from the Nigeria Cereal Research Institute in Ibadan. The grains were cleaned, weighed and washed before steeping in distilled water. 200 gms of cereal grains were used for the kunuzaki production. A control experiment was set up with distilled water without the grains. For the kunu-zaki made from composite grains, an equal weight of grains was used for each part. The laboratory production method followed the traditional process of kunu-zaki fermentation.

\subsection{Composition of the Kunun-Zaki Drinks}

The following nine different formulations of the cereal based kunu-zaki were used:

A $=$ Acha (Hungry rice) Digitaria exilis

$\mathrm{S}=$ Sorghum (Sorghum bicolor)

$\mathrm{M}=$ Millet (Penniseteum americanum)

$\mathrm{AS}=\mathrm{Ach} /$ /Sorghum un-germinated composite grains

$\mathrm{AM}=\mathrm{Ach} /$ Millet Ungerminated composite grains

$\mathrm{SM}=$ Sorghum $/$ millet Ungerminated composite grains

$\mathrm{ASG}=\mathrm{Ach} /$ /Sorghum germinated composite grains
$\mathrm{AMG}=\mathrm{Ach} /$ Millet germinated composite grains $\mathrm{SMG}=$ Sorghum/Millet germinated composite grains. The composite grains were used in the ratio of $1: 1$

\subsection{Germination of Cereal Grains}

$200 \mathrm{~g}$ cereal grains were rinsed in distilled water and drained. Steeping was carried out at a temperature of $48^{\circ} \mathrm{C}$ to a moisture content of about $42 \%-45 \%$. Water was drained and germination carried out by spreading the steeped grains on a tray, in a room at temperature of $28+/-2^{\circ} \mathrm{C}$. Seeds were sprayed intermittently with water. The germinated grains were recovered when the radical was about $1.5 \mathrm{~mm}$ in length.

\subsection{Isolation of Lactic Acid Bacteria}

Samples were obtained from the fermenting germinated and ungerminated cereal grains at $0 \mathrm{hr}, 24$ hours, 48 hours and from the fermenting slurry at 72 hours fermentation time. Figure 1 depicts the traditional process method used in this work for the kunu-zaki production. Samples from these sources were diluted serially 10 -fold in PSB and then inoculated on deMan Rogosa and Sharpe (MRS, Oxoid, England) agar plates by pour plate method [5] MRS agar plates were incubated at $37^{\circ} \mathrm{C}$ for 48 hours anaerobically. Morphologically distinct and well isolated colonies were picked and transferred to new MRS agar plates by streaking. Finally, pure colonies were obtained and preserved for further study.

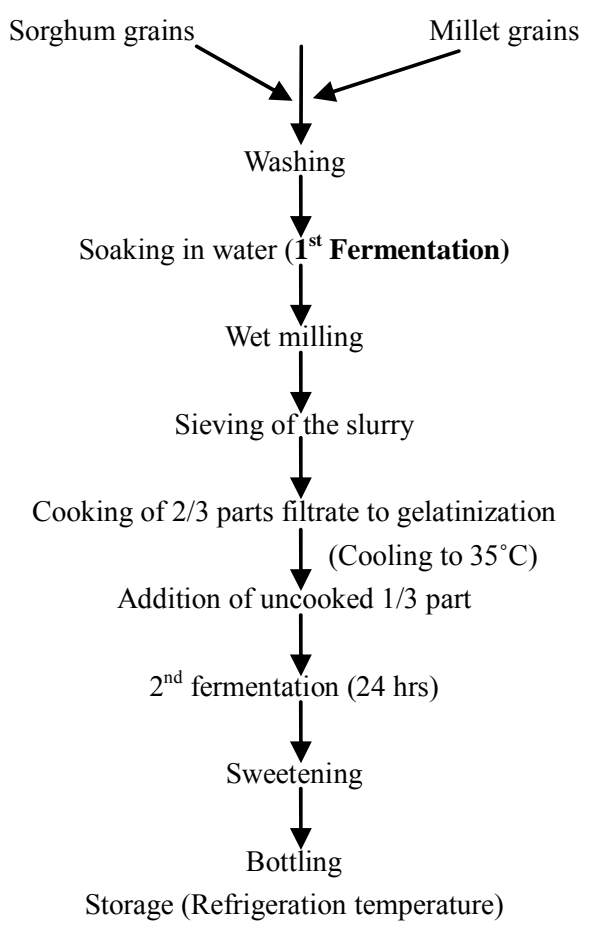

Figure 1. Flow diagram for the traditional processing of kunu-zaki from composite grains. 


\subsection{Identification of Lactic Acid Bacteria Species}

Macroscopic appearance of all the colonies was examined for cultural and morphological characteristics. Size, shape, color and texture of the colonies were recorded. Fresh cultures were used for the gram stain; the cultures were aseptically transferred into tubes and centrifuged at $6000 \mathrm{rpm}$ and the supernatant decanted. The cells were then re-suspended in sterile water, gram stained and observed under the light microscope. Bacterial isolates were tested for catalase production by the catalase test [6]. All the isolates were tested for growth at $\mathrm{pH} 3.0$ and subsequent resistance to $0.3 \%$ bile. Species which were able to grow at $\mathrm{pH} 3.0$ for 3 hours and resisted $0.3 \%$ bile were identified. Identification of species was confirmed using a standard commercial identification system, API50 CHL (Biomerieux ${ }^{\circledR}$, France), according to the manufacturer's instructions. Pure cultures were maintained in MRS broth at $-20^{\circ} \mathrm{C}$ with $10 \%$ (v/v) glycerol.

\subsection{Screening of isolated Lactobacillus Species for Probiotic Properties}

\subsubsection{Resistance to Low $\mathrm{pH}$}

Resistance to $\mathrm{pH} 3$ is often used in vitro assays to determine the resistance to stomach $\mathrm{pH}$. Food usually stays in the stomach for 3 hours and this time limit was taken into account [7]. Active cultures were incubated for $16-18$ hours in MRS broth. The cells were harvested by centrifugation, washed once in phosphate-saline buffer (PBS at $\mathrm{pH}$ 7.2), resuspended in PBS ( $\mathrm{pH} 3$ ) and incubated at $37^{\circ} \mathrm{C}$. Viable microorganisms were enumerated at the 0,1 , 2 and 3 hours with the pour plate technique. Dilutions were done and the resulting plates were incubated at $37^{\circ} \mathrm{C}$ under anaerobic conditions for 48 hours. The growth was also monitored at OD 620 using a T70 UV: VIS spectrometer PG Instruments Ltd.

\subsubsection{Bile Tolerance}

The mean intestinal bile concentration is believed to be $0.3 \%(\mathrm{w} / \mathrm{v})$. The staying time of food in small intestine is suggested to be 4 hours [7]. The experiment was applied at this concentration of bile for 4 hours. MRS medium containing $0.3 \%$ bile (Oxoid) was inoculated with active cultures which had been incubated for 16 - 18 hours). During the 4 hours incubation at $0.3 \%$ bile, viable colonies were enumerated for every hour with the pour plate technique and growth was also monitored at 620 Optical Density-OD 620 (Thermo Multiskan EX).

\subsection{Anti-Microbial Activity Using Spot-on-Lawn Method}

After 18 hours incubation, active cultures were spotted on the surface of MRS agar plates; The plates were incu- bated to grow cultures for 24 hours at $37^{\circ} \mathrm{C}$ under anaerobic conditions. Overnight indicator pathogens were inoculated into soft agar containing $0.7 \%$ agar. Staphylococcus aureus 25923, Escherichia coli 25922, Pseudomonas aeruginosa 27853 and Enterococcus faecalis 29212 as test reference pathogens collected from the Nigerian Institute of Medical research (NIOMER), Yaba, Lagos were used. The inoculated agar was overlaid on MRS plates and incubated at $37^{\circ} \mathrm{C}$ which is appropriate for human pathogens. At the end of the incubation, inhibition zone diameters' surrounding the spotted isolates was measured. Isolates which gave an inhibition zone bigger than $10 \mathrm{~mm}$ was determined to have antimicrobial activity.

\subsection{Identification of Microorganisms}

Isolates which showed growth at $\mathrm{pH} 3.0$ for 3 hours and subsequent resistance to $0.3 \%$ bile for 4 hours, exceeding $10 \mathrm{~mm}$ inhibition zones of antimicrobial activity were the isolates which were identified. The API $50 \mathrm{CH}$ test kit identification method was used. The API $50 \mathrm{CH}$ medium, intended for the identification of the genus Lactobacillus and related genera is a ready-to-use medium which allows the fermentation of the 49 carbohydrates on the API $50 \mathrm{CH}$ strip to be studied. The last one is a blank which serves as a control. A suspension was made on the medium with the microorganism to be tested and each tube of the strip was then inoculated with the suspension. During anaerobic incubation, the carbohydrates are fermented to acids which produce a decrease in the $\mathrm{pH}$ detected by the change in color of the indicator. The results make up the biochemical profile which was used by the API web TM identification software (Ref 40011) Biomerieux to identify the strain.

\section{Results and Discussion}

Lactic acid bacteria (LAB) have been described as Gram positive, catalase negative, cocci or rods non-spore forming bacteria that are aero-tolerant, anaerobic or microaerophilic [8]. They produce lactic acid as part or major by product from fermentation of carbohydrates [8,9]. This group of bacteria includes the following genus Lactobacillus, Pediococcus, Lactococcus, Leuconostoc and Bifidobacterium. The bacteria are responsible for both spontaneous and natural fermentation of sugars [10]. The by-products of food fermentations mediated by LAB, result in an improvement of the aroma, flavor, texture, safety and shelf life of the food.

However, not all LAB are beneficial in foods as some produce lipase and protease which degrade fats and proteins leading to food spoilage [11]. In the present study, Lactobacillus species, Lactococcus species and Pedioсоссиs species were isolated. Before evaluating as probi- 
otic, important characteristics of these organisms were studied. In order to be able to have beneficial effects on the human gut, a candidate potential probiotic strain is expected to have a number of properties. Probiotic strains do not need to fulfill all of the selection criteria but the most important ones are required $[12,13]$. One of the major important criteria is that probiotic destined for human usage should be of human origin [13]. Table 1 shows the species of lactic acid bacteria present in the fermenting mash of kunu-zaki as identified by the API kit. The lactic acid bacteria identified in this work have fulfilled these criteria as all identified species are organisms

Table 1. Identification of isolated lab using the standard API 50 CH test kit method.

\begin{tabular}{|c|c|c|}
\hline Lab significant taxa & $\%$ accuracy & Remarks \\
\hline Lactobacillus plantarum 1 & 98.8 & Very good identification \\
\hline \multicolumn{3}{|l|}{ Lactobacillus rhamnosus } \\
\hline $\begin{array}{l}\text { (Lactobacillus casei } \\
\text { ssp. rhamnosus) }\end{array}$ & 98.6 & Good identification \\
\hline Pediococcus pentosasceus 2 & 99.9 & Excellent identification \\
\hline Pediococcus damnosus 2 & 99.8 & Very good identification \\
\hline Lactobacillus fermentum & 99.6 & Very good identification \\
\hline Lactobacillus cellobiosus & 99.9 & Excellent identification \\
\hline Lactobacillus lindneri & 99.9 & Excellent identification \\
\hline Lactobacillus pentosus & 99.8 & Very good identification \\
\hline Lactobacillus plantarum 1 & 80.6 & Good identification \\
\hline $\begin{array}{c}\text { Lactobacillus paracasei } \\
\text { ssp paracasei } 2\end{array}$ & 99.3 & Very good identification \\
\hline Lactobacillus plantarum 1 & 99.9 & Excellent identification \\
\hline $\begin{array}{c}\text { Lactobacillus paracasei } \\
\text { ssp paracasei } 1\end{array}$ & 99.7 & Very good identification \\
\hline Lactobacillus plantarum 1 & 99.9 & Excellent identification \\
\hline $\begin{array}{c}\text { Lactobacillus paracasei } \\
\text { ssp paracasei } 3\end{array}$ & 99.8 & Very good identification \\
\hline Lactobacillus cellobiosus & 99.9 & Excellent identification \\
\hline Pediococcus damnosus & 99.9 & Excellent identification \\
\hline $\begin{array}{c}\text { Lactobacillus paracasei } \\
\text { ssp paracasei } 3\end{array}$ & 95.8 & Good identification \\
\hline Lactobacillus plantarum 1 & 99.9 & Excellent identification \\
\hline Lactobacillus acidophilus 1 & 91.7 & Good identification \\
\hline Lactococcus lactis ssp lactis 1 & 99.8 & Very good identification \\
\hline Lactobacillus crispatus & 98.3 & Good identification \\
\hline Lactobacillus pentosus & 99.9 & Excellent identification \\
\hline Lactobacillus fructivorans & 99.9 & Excellent identification \\
\hline
\end{tabular}

which are naturally present in the human gut. Probiotics which are acceptable for food/medicine preparations for humans are those which occur naturally in the intestinal tract of healthy human and in foods. Another criteria is that potential probiotic organisms should have acid and bile tolerance which are conditions under which the LAB will have to travel in order to reach the intestine which is the site where any beneficial health effect can be made. Traveling through the human digestive tract can be a challenge for orally administered pro-biotic bacteria. The high acid levels in the stomach and the pancreatic secretions such as digestive enzymes and bile in the small intestine can lead to the injury and death of a percentage of the orally administered probiotic [14]. The mean staying time of food in the stomach is 3 hours, and in this study Lactobacillus pentosus, Pediococcus damnosus, Lactobacillus paracasei ssp paracasei 1, Lactobacillus paracasei ssp paracasei 2 isolated from the fermenting slurry of kunu-zaki showed the greatest resistance to exposure at $\mathrm{pH} 3.0$ with their counts actually increasing after 3 hours exposure. Lactobacillus plantarum, Lactobacilus acidophilus and Lactobacillus fermentum followed closely even though there was a decline in all their viable counts after 3 hours culturing in $\mathrm{pH} 3.0$. Figure 2 shows the variation within each isolated LAB specie cultured at $\mathrm{pH} 3.0$ with respect to time. The Tolerance level of all species to acidic environment was found significantly $(\mathrm{P}<0.05)$ variable. According to [15], enteric lactobacilli are usually able to tolerate $\mathrm{pH} 3.0$ for a few hours, $\mathrm{pH} 2.0$ for several minutes, while viable count will be affected at slightly high acidic $\mathrm{pH}$ and at $\mathrm{pH} 1.0$ all the Lactobacillus species are destroyed. There was a steady increase in viable counts of all species after culturing in bile salt but $L$. paracasei ssp paracasei 1, Pediococcus damnosus, Lactococcus lactis ssp lactis, and Lactobacillus rhamnosus could not maintain an appreciable level of survival after the 3 rd hour. These species experienced a drop in their mean total viable counts between the 3 rd and the 4 th hours of exposure to $0.3 \%$ concentration of bile. Figure 3 shows the variation between the mean total viable counts at exposure to $0.3 \%$ bile salt. These results reveal that lactobacilli responsible for the spontaneous fermentation of kunu-zaki are capable for survival in the environment of the gastrointestinal tract which has characteristic features of having acidic $\mathrm{pH}$ and high concentrations of bile salts. [16] has recorded similar findings in another study: Bile resistance appears to be mediated by bile salt hydrolysis and this results in precipitation of cholesterol. In another research [17], twenty nine Lactobacillus strains of dairy origin were tested in vitro for their probiotic potential. The resistance of the Lactobacillus strains to $\mathrm{pH}$ 1-3 was examined. Tolerance to bile salt was tested against to $0.3 \%$ oxgall. All of the examined strains were resistant to $\mathrm{pH} 3$ during 


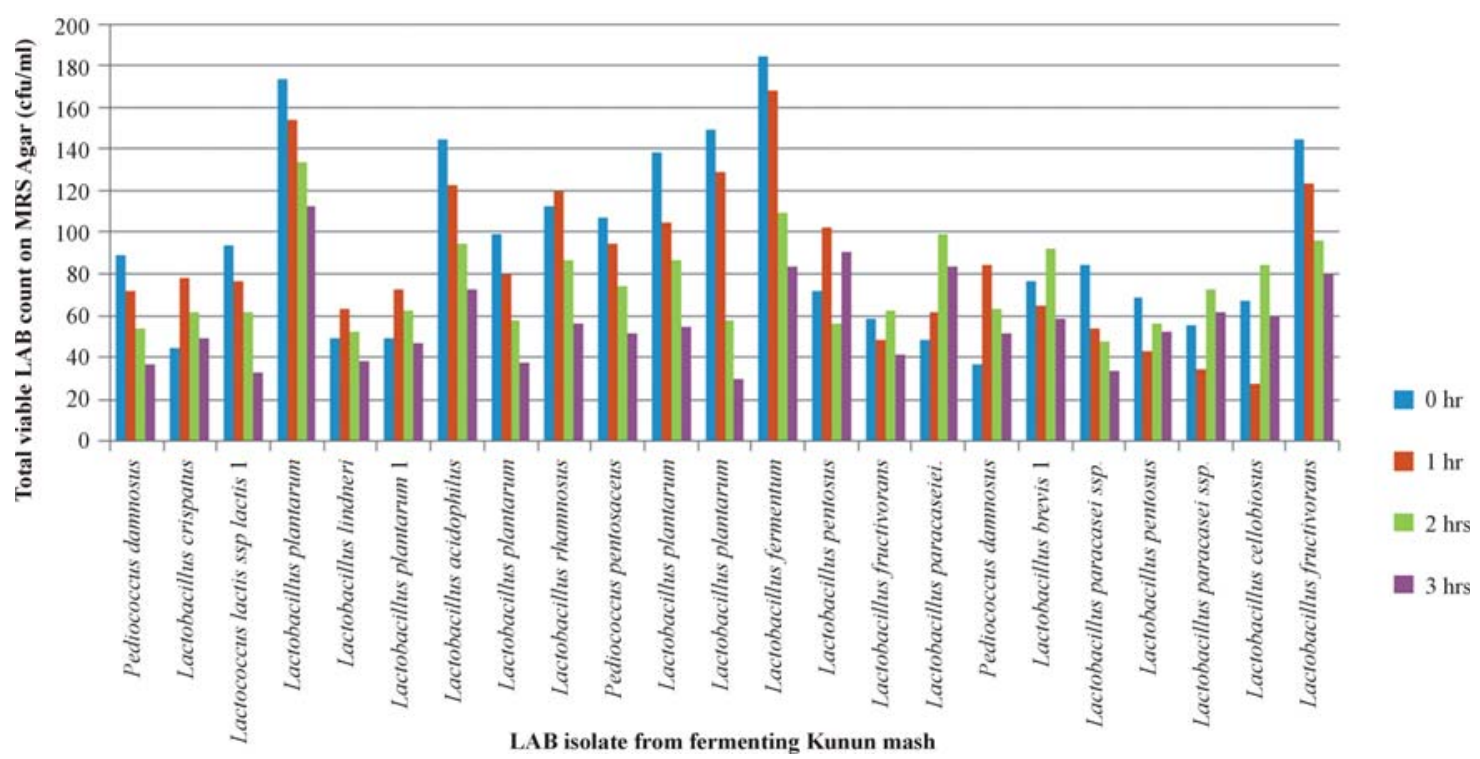

Figure 2. Growth pattern of lab isolates at $\mathbf{p H}=3.0$.

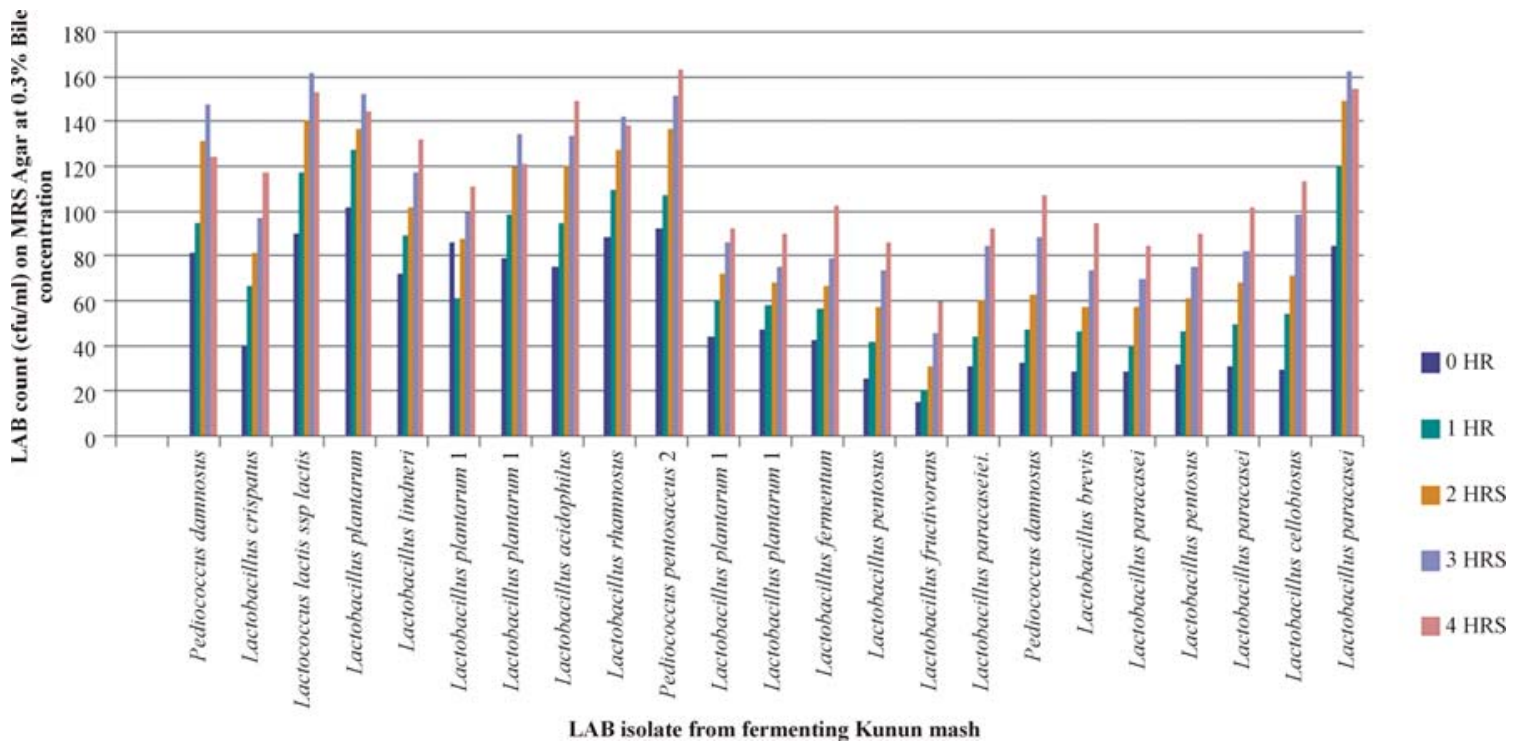

Figure 3. Growth pattern of LAB isolates on MRS agar supplemented with $0.3 \%$ bile.

$3 \mathrm{~h}$, but most of them lost their viability in $1 \mathrm{~h}$ in $\mathrm{pH} 1$. Also all of them tolerated $0.3 \%$ bile salts concentration in $4 \mathrm{~h}$ (Figure 3). All lactobacilli inhibited the growth of $E$. coli, Staphylococcus aureus, P. aeruginosa and E. faecalisexcept $P$. damnosus, Lactococcus lactis ssp lactis1 and Lactobacillus fructivorans that showed significantly $(\mathrm{P}<0.05)$ low antimicrobial effect against $E$. faecalis. The strongest antimicrobial effect was shown by $L$. acidophilus and L. paracasei ssp paracasei 3, Lactobacillus rhamnosus, Lactobacilus fermentum and Lactobacillus pentosus while antimicrobial effect of other lactobacilli was similar against indictor bacteria (Table 2). The antimicrobial action is reportedly due to the potential of LAB to produce lactic acid and bacteriocins [18]. It is also reported that these bacteria produce peptides having inhibitory properties [18]. LABs commonly produce bacteriocins which are peptides with bactericidal activity usually against strains of closely related species. Although bacteriocins may enhance survival of LAB in complex ecological systems interest has focused on prevention of growth of harmful bacteria in the fermentation and preservation of food products, it is more important with respect to probiotic that individual strains may inhibit growth of or adhesion of pathogenic micro-organisms by secreted products, and not merely an effect of acidic $\mathrm{pH}$. Antimicrobial effects of lactic acid bacteria are formed by producing some substances such as organic acids (lactic, acetic, propionic acids), carbon diox- 
ide, hydrogen peroxide, diacetyl, low molecular weight antimicrobial substances and bacteriocins [13,19]. The isolated organisms as identified by the API 50 CHL Test kit are reflected in Table 1. It also gives the percentage of identification accuracy. Lactococcus lactis ssp lactis had good identification only up to the genus level whilst Lactobacillus acidophilus and Lactobacillus paracasei ssp paracasei 3 recorded $91.7 \%$ and $95.8 \%$ identification accuracy. All other LAB isolates recorded above $98 \%$ identification accuracy by the API web TM identification software (Ref 40011) Biomerieux system. Table 3 shows that kunu-zaki made from ungerminated cereal grains had a higher number of probiotic LAB compared to the germinated cereals. Composite formulations also had a higher community of probiotic LAB than the non composite ones. Ungerminated Sorghum and Millet composite formulation accounted for $53 \%$ of the total probiotic LAB isolated. Ungerminated Sorghum non-composite formulation accounted for $23.9 \%$ of the total probiotic LAB isolated whilst ungerminated non composite Millet formulation accounted for $14.25 \%$ of the total probiotic LAB community. The fermenting germinated cereals however recorded a poor score of probiotic LAB community as depicted in Table 4. Ungerminated cereals have been shown by a few researchers to favour the growth of probiotic bacteria. [20] investigated the growth of probiotic Lactobacillus plantarum of human origin on fermented brown rice. Ungerminated fermented brown

Table 2. Antimicrobial activity of LAB isolates against four selected pathogens.

\begin{tabular}{|c|c|c|c|c|}
\hline \multirow[t]{2}{*}{ LAB isolates from spontaneously fermenting kunu mash } & \multicolumn{4}{|c|}{ Inhibition ( $\mathrm{mm} \pm 0.2)$ against tested reference pathogens } \\
\hline & E. coli & S. aureus & P. aeruginosa & E. faecalis \\
\hline L. plantarum (Millet) & 20 & 25 & 23 & 18 \\
\hline L. plantarum 1 (Millet) & 22 & 30 & 26 & 20 \\
\hline P. damnosus (Millet) & 18 & 25 & 24 & 14 \\
\hline P. pentosaceus 2 (Millet Germinated) & 28 & 22 & 23 & 18 \\
\hline L. lindneri (Millet Germinated) & 29 & 21 & 17 & 23 \\
\hline L. plantarum 1 (Sorghum) & 23 & 26 & 21 & 24 \\
\hline L. paracasei ssp para 3 (Sorghum) & 24 & 20 & 29 & 14 \\
\hline L. acidophilus (Sorghum) & 28 & 17 & 20 & 24 \\
\hline L. lactis ssp lactis 1 (Sorghum) & 13 & 16 & 10 & \\
\hline L. crispatus (Sorghum) & 12 & 17 & 17 & 21 \\
\hline L. rhamnosus (Sorghum-Millet) & 29 & 18 & 24 & 26 \\
\hline P. damnosus (Sorghum-Millet) & 18 & 21 & 25 & - \\
\hline L. fermentum (Sorghum-Millet) & 28 & 24 & 26 & 18 \\
\hline L. plantarum 1 (Sorghum-Millet) & 29 & 29 & 25 & 15 \\
\hline L. paracasei spp para 1 (Sorghum-Millet) & 28 & 24 & 26 & 14 \\
\hline L. paracasei spp para 3 (Sorghum-Millet) & 26 & 21 & 30 & 22 \\
\hline L. cellobiosus (Sorghum-Millet) & 27 & 18 & 22 & 23 \\
\hline L. plantarum (Sorghum-Millet) & 15 & 20 & 20 & 15 \\
\hline L. pentosus (Sorghum-Millet) & 29 & 18 & 23 & 17 \\
\hline L. pentosus (Acha + Millet) & 22 & 22 & 27 & 18 \\
\hline L.brevis (Acha + Millet) & 23 & 18 & 30 & 14 \\
\hline L. fructivorans (Acha + Millet Germinated) & 20 & 19 & 27 & - \\
\hline L. paracasei ssp para $2($ Acha + Sorghum $)$ & 11 & 22 & 24 & 13 \\
\hline
\end{tabular}

- = no inhibition 
Table 3. Probiotic LAB isolated from ungerminated composite and non composite fermenting grains.

\begin{tabular}{|c|c|}
\hline Source of isolation & $\begin{array}{l}\text { Significant Probiotic } \\
\text { LAB bacteria isolated }\end{array}$ \\
\hline \multicolumn{2}{|c|}{$\begin{array}{l}\text { Fermenting non composite } \\
\text { ungerminated grain }\end{array}$} \\
\hline Millet & $\begin{array}{l}\text { Lactobacillus plantarum } 1 \\
\text { Lactobacillus plantarum } \\
\text { Pediococcus damnosus }\end{array}$ \\
\hline \multirow[t]{5}{*}{ Sorghum } & Lactobacillus plantarum 1 \\
\hline & Lactobacillus paracasei ssp para 3 \\
\hline & Lactobacillus acidophilus \\
\hline & Lactococcus lactis \\
\hline & Lactobacillus crispatus \\
\hline \multicolumn{2}{|l|}{$\begin{array}{l}\text { Fermenting composite } \\
\text { ungerminated grain }\end{array}$} \\
\hline \multirow[t]{8}{*}{ Millet + Sorghum } & Lactobacillus rhamnosus \\
\hline & Pediococccus damnosus \\
\hline & Lactobacillus fermentum \\
\hline & Lactobacillus paracasei spp para 1 \\
\hline & Lactobacillus paracasei spp para 3 \\
\hline & Lactobacillus cellobiosus \\
\hline & Lactobacillus plantarum \\
\hline & Lactobacillus pentosus \\
\hline Acha + Millet & Lactobacillus pentosus \\
\hline Acha + Sorghum & Lactobacillus paracasei ssp pa ra 2 \\
\hline
\end{tabular}

Table 4. Probiotic LAB isolated from germinated composite and non composite fermenting grains.

\begin{tabular}{cc}
\hline Source of isolation & $\begin{array}{c}\text { Significant Probiotic LAB } \\
\text { bacteria isolated }\end{array}$ \\
\hline $\begin{array}{c}\text { Fermenting non composite } \\
\text { germinated grain } \\
\text { Millet }\end{array}$ & Pediococcus pentosaceus \\
Fermenting composite \\
germinated grain \\
Acha + Millet
\end{tabular}

rice was found to support the growth of probiotic Lactobacillus plantarum. Literature is quite scanty on the comparative effects of germination and fermentation on the total microbial community of fermenting cereals. [21] were able to demonstrate that the total LAB community in malted cowpea fortified fermented cereal was time related. Their work, however, did not compare with the unmalted counterpart. This study has shown that germination does have an effect on the total probiotic LAB isolated.

\section{Conclusion}

It is concluded that the test species of Lactic acid bacteria present in spontaneously fermenting kunu-zaki have the potential ability to survive in the gastrointestinal tract of human. Since the species isolated are also found as normal commensals of the human GIT, the LAB species identified by this work can be used as probiotic in human preparations. It can also safely be concluded that kunuzaki made from ungerminated Sorghum and Millet composite cereal grains will have very good applications as a natural probiotic drink.

\section{Acknowledgements}

The author acknowledges the following for their helpful comments and contributions during the course of this work: Olu Odeyemi, School of Bioscience and Biotechnology, University of Malaysia, Olu Malomo, Director, Central Research Laboratory, Bells University of Technology and Biotechnology Division, Federal Institute of Industrial Research, Oshodi. The author also acknowledges the support of the grant received towards scientific research from the Education Trust Fund through the Yaba College of Technology.

\section{REFERENCES}

[1] T. R. Klaenhammer, "Probiotic Bacteria: Today and Tomorrow," Journal of Nutrition, Vol. 130, Suppl. 2S, 2000, pp. 415S-416S.

[2] T. Gaffa, I. A. Jideani and T. Nkama, "Traditional Production, Consumption and Storage of Kunu-A NonAlcoholic Cereal Beverage," Plant Foods for Human Nutrition, Vol. 57, No. 1, 2002, pp. 73-81. doi:10.1023/A:1013129307086

[3] J. A. Jideani and J. O. Akingbala, "Some Physiochemical Properties of Acha (Digitaria exilis Stapf) and Iburua (Digitaria iburua Stapf) Grains," Journal of the Science of Food and Agriculture, Vol. 63, No. 3, 1993, pp. 369-371. doi:10.1002/jsfa. 2740630317

[4] J. A. Ayo, I. Nkama, U. S. Haruna, Y. Bitrus and F. Onajaife, "Effect of Dough Improvers on the Physical and Sensory Quality of Acha (Digitaria exilis) Flour Bread," Nigerian Food Journal, Vol. 26, No. 1, 2008, pp. 102110.

[5] J. A. Awan, and S. U. Rahman, "Microbiology Manual," Unitech Communications, Faisalabad, 2005, pp. 49-51.

[6] W. F. Harrigan and M. E. McCance, "Methods in Food and Dairy Microbiology," Academic Press, London, 1976.

[7] J. Prasad, H. Gill, J. Smart and P. K. Gopal, "Selection and Characterization of Lactobacillus and Bifidobacte- 
rium Strains for Use as Probiotic," International Dairy Journal, Vol. 8, No. 12, 1998, pp. 993-1002. doi:10.1016/S0958-6946(99)00024-2

[8] B. J. B. Wood and W. H. Holzapfel, "The Genera of Lactic Acid Bacteria in the Lactic acid Bacteria," In: B. J. B. Wood and W. H. Holzapfel Eds., The Genera of Lactic Acid Bacteria Blackie, Academic and Professional, London, 1995, p. 398. doi:10.1007/978-1-4615-5817-0

[9] K. H. Steinkraus, "Fermentations in World Food Processing," Comprehensive Reviews in Food Science and Food Technology, Vol. 1, No. 1, 2002, pp. 23-32. doi:10.1111/j.1541-4337.2002.tb00004.x

[10] V. Lei and M. Jacobsen, "Microbiological Characterization and Probiotic Potential of Koko and Koko Sour Water African Spontaneously Fermented Millet Porridge and Drink," Journal of Applied Microbiology, Vol. 96, No. 2, 2004, pp. 384-397. doi:10.1046/j.1365-2672.2004.02162.x

[11] C. M. Kalui, J. M. Mathara and P. M. Kutima, "Probiotic Potential of Spontaneously Fermented Cereal Based Foods-A Review," African Journal of Biotechnology, Vol. 9, No. 17, 2010, pp. 2490-2498.

[12] A. C. Quwehand, P. V. Kirjavainen, C. Shortt and S. Salminen, "Probiotics: Mechanisms and Established Effects," International Dairy Journal, Vol. 9, No. 1, 1999, pp. 43-52. doi:10.1016/S0958-6946(99)00043-6

[13] İ. Çakir, "Determination of Some Probiotic Properties on Lactobacilli and Bifidobacteria," PhD Thesis, Ankara University, Ankara, 2003.

[14] P. R. Marteau, M. Minekus, R. Havenaar, and J. H. J. Huis Int'l Veld, "Survival of Lactic Acid Bacteria in a Dynamic Model of the Stomach and Small Intestine. Validations and the Effect of Bile," Journal of Dairy Science, Vol. 80, No. 6, 1997, pp. 1031-1037. doi:10.3168/jds.S0022-0302(97)76027-2

[15] W. P. Charteris, P. M. Kelly, L. Morelli and J. K. Collins,
"Selective Detection, Enumeration and Identification of Potentially Probiotic Lactobacillus and Bifidobacterium Species in Mixed Bacterial Populations," International Journal of Food Microbiology, Vol. 35, No. 1, 1997, pp. 1-27. doi:10.1016/S0168-1605(96)01222-6

[16] T. R. Klaenhammer and M. J. Kullen, "Selection and design probiotic," International Journal of Food Microbiology, Vol. 50, No. 1, 1999, pp. 45-57. doi:10.1016/S0168-1605(99)00076-8

[17] P. A. Maragkoudakis, G. Zoumpopoulou, C. Miaris, G. Kalantzopoulos, B. Pot and E. Tsakalidou, "Probiotic potential of Lactobacillus Strains Isolated from Dairy Products," International Dairy Journal, Vol. 16, No. 3, 2005, pp. 189-199. doi:10.1016/j.idairyj.2005.02.009

[18] M. Strus, K. Pakosz, H. Gościniak, A. Przondo-Mordarska, E. Rozynek, H. Pituch, F. Meisel-Mikołajczyk and P. B. Heczko, "Antagonistic Activity of Lactobacillus Strains against Anaerobic Gastrointestinal Tract Pathogens (H. pylori, C. coli, C. jejuni, C. difficile)," Medycyna Doswiadczalna i Mikrobiologia, Vol. 53, No. 2, 2001, pp 133-142.

[19] A. C. Quwehand and S. Vesterlund, "Antimicrobial Components from Lactic Acid Bacteria. Lactic Acid Bacteria Microbiological and Functional Aspects," Marcel Dekker Inc., New York, 2004.

[20] P. Saman, P. Fuciños, J. A. Vázquez and S. S. Pandiella, "Fermentability of Brown Rice and Rice Bran for Growth of Human Lactobacillus Plantarum NCIMB 8826," Food Technology \& Biotechnology, Vol. 49, No. 1, 2011, p. 128.

[21] S. L. Wakil and A. A. Onilude, 2011 "Time Related Total Lactic Acid Bacteria Population Diversity and Dominance in Cowpea-Fortified Fermented Cereal-Weaning Food," African Journal of Biotechnology, Vol. 10, No. 6, 2011, pp. 887-895. 